\title{
CrimRxiv
}

\section{Shadow Libraries: Access to Knowledge in Global Higher Education}

Joe Karaganis

Published on: May 01, 2018

DOI: $10.21428 / c b 6 a b 371.76 a e 82 b b$

License: Creative Commons Attribution 4.0 International License (CC-BY 4.0). 
